\title{
Media Role in the Civic Engagement Patterning of Indonesian Civil Society
}

\author{
Dewi Kartika Sari \\ Communication Science Department \\ Universitas Kristen Satya Wacana \\ Salatiga, Indonesia \\ dewi.kartika@staff.uksw.edu
}

\author{
Nur Aji Wibowo \\ Physics Department \\ Universitas Kristen Satya Wacana \\ Salatiga, Indonesia \\ aji.wibowo@staff.uksw.edu
}

\begin{abstract}
The phenomenon of crowdfunding now becomes an interesting experience because of its success in raising a huge amount of funds from civil society to overcome the social issues. In fact, the aid flows voluntarily even with no driven force. Some cases are free Umroh facility as well as grant money for a police officer named Bripka Ase Kusmana by Cipanas residents, fundraising for elderly couples with down syndrome children in Kulon Progo, and crowdfunding for the payment of diyat for Indonesian worker from Ungaran. These kinds of behaviors cannot be separated from the presence of the civic engagement which allegedly new media plays an important role in construct, develop, and reinforce on it. In this paper, the qualitativeexplorative investigation was conducted not only focuses on the motive of the civic engagement but also how its patterns occur therewith the possible impacts it may cause. Meanwhile, two fundamental theories, i.e., civic engagement, and social action media theory, were used to analyze the collected data. The results show that the civic engagement in civil society builds up not only were catalyzed by the media, and emerging of past issues but also because of the use of marginalization issues in generating empathic feeling as civilians.
\end{abstract}

Keywords-new media; civic engagement; crowdfunding; Indonesia citizens

\section{INTRODUCTION}

The phenomenon of new media usage in Indonesia is always interesting to observe. Based on data from tekno.kompas.com, the number of social media users in Indonesia of 130 million people from the total population in Indonesia as of January 30, 2018, amounted to 264.5 million people [1]. This means that social media users in Indonesia account for 49 percent of the total population of Indonesia. Data from kompas.com quoted from the results of We Social research further conveys the order of platforms most widely accessed by social media users in Indonesia. Youtube is currently the first platform to be accessed by new media users in Indonesia, followed by Facebook, Whatsapp, Instagram, Line, BBM, Twitter, Google+, FB Messenger, LinkedIn, Skype and WeChat.

Compared to other countries, the number of social media users in Indonesia shows a significant number. Based on information from liputan6.com as of April 2018, Facebook users in Indonesia ranks third in the world after India and the United States. Instagram users in Indonesia ranks fourth in the world with a total of 56 million users. United States ranks first in the number of Instagram users, followed by Brazil, and India. Twitter users in Indonesia are not included in the category of the world's top five. The number of Twitter users in Indonesia is ranked twelfth with the number of users of 6.6 million people [2]. Based on these data, research on the use of social media in Indonesia is still able to be developed.

As a country with a large number of social media users in the world, the phenomenon of new media use will continue to be the attention of researchers. One of the phenomena of new media usage which is interesting to be studied is crowdfunding phenomenon. Crowdfunding is a donor fundraising activity for a particular project [3]. There are various activities involving crowdfunding as one of its activities or crowdfunding as its main activity. This paper presents an analysis of crowdfunding activities for the \#SaveSatinah case, Umroh facility to Bripka Ase, a donation to Bripka Ase, as well as donations for elderly couples who have down syndrome children. Based on those empirical problems, what is the role of new media in establishing the civic engagement of Indonesian society in all three cases? The objective of this research is to know the role of new media in shaping civic engagement of Indonesian society in case \#SaveSatinah, Umroh facility as well as a donation to Bripka Ase, and donation for an elderly couple who struggle for their child's education who have down syndrome.

\section{TheORETICAL REviEW}

\section{A. New Media}

The term 'new' on the phrase 'new media' has a broad meaning. Lister et.al provides six terms to describe new media. The six terms are digital, interactive, hypertextual, virtual, networked, and simulated. These six terms can be regarded as characteristics of new media. Characteristics can be understood as the core qualities possessed by new media [4].

\section{B. The Role of New Media}

New media has a role as a transmitter as well as a producer for the community. New media seems to be a solution for all the needs that exist in the community. This means that new media can also be a source for the community. The characteristics of new media as a source, transmitter, or 
producer are due to new media having decentralized, low investment, providing high interactivity, providing great public participation and difficult to control [5].

\section{Civic Engagement}

Civic engagement is a concept that is often used but still difficult to formulate its meaning. Civic engagement has a broad meaning. In order to understand it easily, the authors used civic engagement indicators according to Keeter, et.al. Keeter et.al. provides three indicators of civic engagement, namely: (1) Community problem solving; (2) volunteering; (3) Group or organizational membership. These three indicators will be used to analyze the three cases that the author chose [6].

\section{Social Action Media Theory}

Littlejohn and Foss [7] categorize Social Action Media Theory (SAMT) into the theory of elements of Media communication. In the element of media communication, SAMT belongs to sociocultural theories. In the sociocultural theories group, the media is assumed to have very strong power or strength. This means that media productions are a form of response from social and cultural developments in society. And later social and cultural life of society also affect the development of media production.

\section{METHODS}

This research uses the qualitative approach with explorative research type. Data collection techniques conducted by analyzing documents in the form of news in the online newspaper; analyze the content on the website Kitabisa.com, Facebook, and Twitter.

\section{RESULTS AND DisCUSSION}

\section{A. Civic Engagement Cases Satinah, Bripka Ase, and Elderly Couple who have a Down Syndrome Children}

Data were analyzed using the concept of civic engagement according to Keeter et al. Keeter et al. formulate three indicators in formulating of public ties. These three indicators: (1) Community problem-solving. Community problem solving is concerned with informal community collective action aimed at solving problems in the community. This collective action can also mean inter-community relationships that form a cooperative to solve problems; (2) volunteering. Volunteering is grouped into regular volunteering and non-regular volunteering. (3) Group or organizational membership. The membership referred to in this concept is an active membership or an inactive membership of a person in a group or organization.

The first case to be analyzed by civic engagement indicator according to Keeter et.al is the Satinah case. The Satinah case was previously studied but used the concept of a new social movement in a virtual public space [8]. The Case of Satinah has not been studied using the civic engagement approach, therefore, in this paper, the Satinah case will be analyzed by using the civic engagement approach. Community problemsolving in Satinah case is done by informal collective action. There is no special organization that overshadowed this case. The problem to solve is to help Satinah to be free from beheading by paying diyat of 21 billion rupiahs. Community action is giving their support on Twitter with \#SaveSatinah. Another action the community undertakes is to voluntarily donate funds which are then sent to Melanie Subono's account. Melanie Subono is an Indonesian artist who supports the movement for the liberation of Satinah. This donation of funds is a volunteering action in the concept of civic engagement according to Keeter et.al. The third concept is community membership. The nature of membership of this people is people that has a Twitter account and uses it. The author, in this case, cannot determine exactly how active the public uses their Twitter. In other words, the active concept intended here is active in using Twitter. To achieve the objective of crowdfunding, the issue used is the issue of marginal society. Satinah as a female worker (TKW) represents a marginal group that does not get the attention of the Government which ultimately must be defended and assisted. The end result of this case is the Government of the Republic of Indonesia redeem money diyat Satinah taken from the State Budget Revenue. The ransom also comes from donations [9].

The second case to be analyzed is the departure of Umroh and donation for Bripka Ase who is a member of the police in Cipanas. News about the action of citizens to raise funds for Bripka Ase is published in several national newspapers, one of them is Tribunnews Jambi [10]. In the article in Tribunnews is written about the actions of citizens who collect donations through social media Facebook. One of the Facebook pages referred by Tribunnews is Cut Meutia Adrina's Facebook account. Referring to the concept of civic engagement Keeter et.al, community problem-solving, is a resident in the area of Bripka Ase in charge of expressing their gratitude for the service of Bripka Ase [11]. Bripka Ase is remembered as a member of the traffic police who often helps solve traffic problems and often helps people cross the road in his area of duty, namely in the Cianjur Police area, especially in Cipanas. The second part of volunteering is realized in the form of free Umroh departure by travel agent Umroh and donation amounting to Rp14.100.000,00 from residents to Bripka Ase. The third part of civic engagement is membership in groups or groups. Communities that give Umroh and donation prizes are not tied to group or formal membership within an organization, but they are the owners of Facebook accounts with experience with Bripka Ase. The issue used to create civic engagement, in this case, is to use past memory. The people who donate to Bripka Ase are the people who once helped by Bripka Ase. When they were kids, Bripka Ase often helped them to cross the street. This past memory is able to bind the local community so they donate to Bripka Ase.

The third case analyzed was an elderly couple who took their down-syndrome children to school. The distance between the house to school about 11 kilometers. The distance is cycled for 60 minutes every day. The story of the elderly 
couple who fought for their son's education is down syndrome is reported in some national news, Kompas.com [12]. Community problem-solving is the public wants to help the elderly couple who traveled a dozen miles each day with cycling to take his child who has limitations. At the end of the news, Kompas.com provides information that Kompas.com cooperate with Kitabisa.com to accommodate funds from readers who want to donate funds to help the elderly couple. Kitabisa.com is a specialized fundraising website for anyone who wants to help and be given to anyone who wants to be helped. The fundraising result for the elderly couple is $\mathrm{Rp}$ $210,046,594.00$ [13]. Fundraising is a form of volunteering in the concept of civic engagement developed by Keeter, et.al. The third part is membership in groups. The nature of membership in this group is the readers of Kompas.com and the people listed on Kitabisa.com. The issue used to create civic engagement is the issue of marginalization. Marginalization arises in the form of an elderly couple who have only one child, the child is suffering from Down syndrome, and the couple every day deliver their children to school by traveling $11 \mathrm{~km}$ by bike. The issue of marginalization eventually led to a sense of compassion and empathy that led to the invitation to donate to the elderly couple.

\section{B. Platform Utilized In Forming Civic Engagement}

As mentioned earlier, the three cases use different platforms to raise funds. There are three platforms used for crowdfunding in all three cases. The third platform is Twitter which is a form of microblogging, Facebook as one form of social media, and Kitabisa.com is a website to raise funds from the community. All three platforms are used with the same goal of raising funds from the community or crowdfunding.

All three platforms, according to the author's observation, need also traditional media. The traditional media in question is an online newspaper. Online newspapers include tribunnews.com and kompas.com. The online newspaper contributed to the success of crowdfunding in all three cases analyzed. This traditional media, the newspaper, has converged with new media. The form of convergence is news on the online newspaper. The combination of traditional media and new media influences and is influenced by all activities and activities that occur in the community. The interplay between media and society in accordance with Social Action Media Theory which states that media production is a response from the social and cultural development of society. The social and cultural development of the society also influences media production.

\section{The Role of New Media: As a Catalyst?}

The catalyst according to https://en.oxforddictionaries.com is a substance capable of increasing the reaction without altering the character of the substance. In that sense, the catalyst has a synonym for the word channel, medium, instrument, mechanism. Another meaning of catalyst in the dictionary can also be interpreted as someone or something that can speed up an event. Synonyms of this word include stimulus, stimulation, boost, impulse. In the context of Communication Science, the term channel or medium is often used to describe the elements of media communication. In the context of Communication Science also, the media is a stimulus to accelerate an event.

The three cases analyzed by the authors prove the media has a role as a channel or medium or a stimulus or catalyst. In the case of Satinah, \#SaveSatinh on Twitter speeds up message delivery on the Twitter system. In the case of Bripka Ase, Facebook accelerates fundraising information on the Facebook system, and in the case of the elderly who send their children down syndrome, Kitabisa.com provides a container to accommodate community donations. Use of Twitter, Facebook, and Kitabisa.com accelerate the spread of events to the public with the news in the online newspaper. Research on the importance of the role of mass media and online media in the community has been widely practiced. Two of them are studies conducted by Happer and Pilo [14] and research conducted by Lim [15]. Happer and Pilo stated that the media has a major role in communicating information to the public. The research also states the importance of traditional and new media roles that may help disseminate better information in the community. Meanwhile, Lim stated that the media has a role as an amplifier that is to echo the issues that exist in society.

\section{REFERENCES}

[1] W. K. Pertiwi, "Riset Ungkap Pola Pemakaian Medsos Orang Indonesia [Research Reveals Indonesian Social Media Usage Pattern],” KOMPAS.com, March 1, 2018.

[2] T. Kurnia, "5 Negara Dengan Jumlah Pengguna Media Sosial Terbanyak, Indonesia Berapa? [Five Countries with the Most Social Media Users, On What Number Indonesia falls?]” liputan6.com, April 24, 2018.

[3] M. Irfan, “Crowdfunding Sebagai Pemaknaan Energi Gotong Royong Terbarukan [Crowdfunding as the Renewable Gotong-Royong Energy],” Share Soc. Work J., vol. 6, no. 1, Jul. 2016.

[4] M. Lister, J. Dovey, G. Seth, I. Grant, and K. Kelly, New Media: A Critical Introduction. New York USA: Routledge, 2009.

[5] L. Rajendran and P. Thesinghraja, "The Impact of New Media on Traditional Media,” Middle-East J. of Sci. Res., vol. 22, no. 4, pp. 609616, 2014.

[6] S. Keeter, K. Jenkins, C. Zukin, and M. Andolina, "Three Core Measures of Community-Based Civic Engagement: Evidence from the Youth Civic Engagement Indicators Project,” presented at the Child Trends Conference on Indicators of Positive Development, Washington, DC, 2003.

[7] S. W. Littlejohn and K. A. Foss, Theories of Human Communication, 8th ed. Canada: Thomson Learning Inc., 2005.

[8] D. K. Sari and R. R. Siahainenia, "Gerakan Sosial Baru di Ruang Publik Virtual pada Kasus Satinah [New Social Movement in Virtual Public Space on Satinah's Case]," Jurnal Ilmu Komunikasi, vol. 12, no. 1, pp. 105-118, 2015.

[9] B. Adikara, "Satinah Lolos dari Hukuman pancung Karena Bayar Rp 21 Miliar - Tribunnews.com [Satinah Free from Train Law as Rp21 billion was Paid - Tribunnews.com],” September 03, 2015.

[10] Anonim, "FOTO: Umrah dan Uang, Hadiah untuk Bripka Ase, Polisi 'Legendaris' di Cipanas [PHOTO: Umrah and Money, Price for Bripka Ase, 'Legendary' Police in Cipanas],” Tribun Jambi, June 26, 2017.

[11] R. Belarminus, “Bripka Ase, Polantas 'Legendaris' di Cianjur yang Viral Karena Pengabdiannya [Bripka Ase, 'Legendary' Traffic Police that Viral due to his Service],” KOMPAS.com, May 31, 2017. 
[12] D. J. Zebua, "Suami Istri Lansia 'Ngontel' Setiap Hari dari Hutan ke Kota Antar Anaknya yang 'Down Syndrome' ke Sekolah Kompas.com [Elderly Husband and Wife Rides Bicycles Daily from the Forest to the City, Taking Their Down Syndrome Child to School]," March 28, 2018.

[13] Admin, "Kitabisa.com - Search Page." [Online]. Available: https://kitabisa.com/search?keyword=kompas.com\&page=3.

[Accessed: Jun. 17, 2018].
[14] C. Happer and G. Philo, "The Role of the Media in the Construction of Public Belief and Social Change,” J. Soc. Polit. Psychol., vol. 1, no. 1, pp. 321-336, Dec. 2013.

[15] M. Lim, "The Internet and Everyday Life in Indonesia: A New Moral Panic?,” Bijdragen tot de Taal-, Land- en Volkenkunde / J. of the Human. and Soc. Sci. of Southe. Asia and Ocea., vol. 169, no. 1, pp. 133-147, Jan. 2013. 